\title{
KONSEP ART DALAM DESAIN ANIMASI
}

\author{
Arief Agung Suwasono \\ Desain Komunikasi Visual \\ Institut Seni Indonesia Yogyakarta \\ arif.agung.suwasono.67@gmail.com
}

\begin{abstract}
Concept art is not the same as illustration, It's about creating a single artistic vision that can power a franchise. The main goal of concept art is to convey a visual representation of a design, idea, and/or mood for use in films, video games, animation, or comic books before it is put into the final product. In other words, it aims to convey the overall design vision rather than specify everything in exact terms right at the start. In this article, I'll look into exactly what concept art involved and how it's an essential part of the modern entertainment franchise process. The research method used is qualitative research with the approach of art and design and preferably on the creative aspect. The result of this research is a model of concept art for designing animated film, especially at the stage of creative concept.
\end{abstract}

Keywords: Concept art, animation

\section{PENDAHULUAN}

Konsep seni atau yang lebih mudah diingat oleh para mahasiswa seni dan desain dengan istilah concept art, adalah bentuk ilustrasi yang digunakan untuk menyampaikan sebuah ide yang digunakan untuk keperluan pembuatan film, video game, animation, komik, dan beberapa media lain, sebelum diwujudkan dalam produk akhir. Concept art juga mengacu kepada pengembangan visual design atau konsep desain. Istilah concept art ini juga bisa diaplikasikan untuk kepentingan desain industri, fashion, seting untuk perfilman, dan sebagainya. (Istilah concept art ini selanjutnya disingkat dengan CA). CA sering diidentikkan dengan ilustrasi, akan tetapi meskipun wujud dari CA adalah ilustrasi, CA pada dasarnya adalah sebuah konsep desain. CA datang dari kepentingan sebuah industri. CA lahir dari kreatifitas para pelaku industri kreatif, yang menginginkan produk desainnya diterima oleh masyarakat. Dengan demikian CA adalah sebuah konsep desain yang menyesuaikan diri dengan tujuan desain.

Dalam industri animasi di Indonesia, CA masih sering dimengerti sebagai konsep pembuatan karakter. Meskipun daya tarik animasi terletak pada gambaran karakter, akan tetapi CA tidak hanya sebatas karakter, akan tetapi seluruh materi visual yang akan muncul pada film animasi, seharusnya dilahirkan dari finalisasi CA. Di sisi lain 
beberapa studio animasi memandang CA dengan cara pandang dan akurasi yang berbeda. Hal ini disebabkan ada idealisme dan pengalaman estetik yang berbeda dari illustrator dengan animator atau mungkin dari produser, sehingga model CA di setiap studio animasi tidak sama. Shamsuddin dalam penelitian tentang CA, mengatakan bahwa memang terdapat model yang berbeda-beda dari studio-studio animasi saat ini. (Journal of Modern Science and Technology Vol. 2. 2014) Para pelaku industri animasi memiliki wawasan seni dan komunikasi visual yang berbeda. Apalagi industri animasi adalah industri yang berkaitan dengan bisnis kreatif. Antara seni, desain dan bisnis menjadi satu.

Terlepas dari pendekatan kreatif yang berbeda di beberapa studio animasi, CA sendiri adalah model konsep yang harus dimatangkan dalam tahapan pembuatan film animasi, atau pra produksi. CA merupakan gambaran bagaimana materimateri visual diidentifikasi dan divisualisasikan sebagai pedoman artistik dari para animator sebelum masuk dalam proses produksi (animating).

"Innovative and creative conceptions are fundamental for advancement of animation technology. Knowledge and intelligence of concept art are very essential to visualize the development of final appearance of animation. These are the essentials for visual demonstration of design, idea, and mood" (Shamsuddin: 2014).

\section{METODOLOGI}

Penelitian yang digunakan adalah bersifat kualitatif, yang lebih memfokuskan pada pendalaman konsep art, sebagai bagian dari tahapan pra produksi dalam perancangan film. Adapun pendekatan yang digunakan lebih pada kreatif estetik, untuk mencari dan menemukan bagaimana suatu model dapat digunakan untuk memecahkan permasalahan dalam desain. Kreatif estetik sendiri menurut Nick Zangwil (2007; 36) mempunyai pengertian kemampuan dari seseorang untuk mengolah benda atau properti yang tidak mempunyai sifat keindahan, menjadi tampak indah di tangan seseorang yang mempunyai pengalaman dan wawasan estetika. Objek dapat menjadi sesuatu yang tampak artistik saat seorang seniman menghasilkan pengalaman yang merangsang orang lain menganggap obyek tersebut memiliki keunggulan artistik.

CA dianalisis dengan memahami terlebih dahulu apa yang menjadi kepentingan pembuatan animasi, sebagai tahap identifikasi, selanjutnya dirumuskan model pengembangan (development model) dengan menetapkan materi-materi visual apa saja yang dapat dijadikan pedoman 
dalam sebuah concept art dengan pertimbangan kreatif estetiknya. Materi visual dapat dikembangkan secara luas dan imajinatif sesuai wawasan estetik illustrator yang membahasakan sebuah desain yang merepresentasikan ide dan mood dalam kerangka cerita film.

\section{Hasil Penelitian}

Penelitian ini menghasilkan model CA yang dikaji dari beberapa pengembangan artistik. Yang harus dipahami oleh pembuat CA bahwa animasi adalah sebuah ilusi mata dari rangkaian gambar-gambar (persistence of illusion), yang hidup di mata penonton. Dari sini, seperti kata Laybourne, maka semua obyek atau gambar dapat dihidupkan, dalam arti bergerak seperti hidup dan bernyawa. Konsep art dalam animasi, tidaklah hanya semata menuangkan gagasan tentang bagaimana bentuk karater animasinya, atau bagaimana membuat ilustrasi tentang karakter itu sendiri. Dalam beberapa literatur cetak dan elektronik, konsep art dipahami sebagai segala sesuatu yang nantinya dinyatakan sebagai konsep dalam bentuk ilustrasi yang digunakan untuk menyampaikan ide untuk digunakan dalam film, video game, animasi, buku komik atau media lainnya sebelum dimasukkan ke dalam produk akhir. Konsep art juga disebut sebagai pengembangan visual dan/atau desain konsep. Istilah ini juga bisa diterapkan pada desain retail, set, fashion, arsitektural dan industri. CA dikembangkan dalam beberapa literasi. Seniman mencoba beberapa desain untuk mencapai hasil yang diinginkan untuk pekerjaan, atau terkadang mencari hasil yang menarik. Desain disaring dan disempurnakan secara bertahap untuk mempersempit pilihan. Konsep art tidak hanya digunakan untuk mengembangkan karya, tapi juga untuk menunjukkan kemajuan proyek kepada direksi, klien dan investor.

CA pada dasarnya adalah patron. CA adalah seni yang sangat dipoles yang digunakan untuk mempromosikan film dan game yang akan datang. Tujuan utama dari konsep art adalah untuk menyampaikan representasi visual dari sebuah desain, gagasan, dan/atau suasana hati untuk digunakan dalam film, permainan video, animasi, atau buku komik sebelum dimasukkan ke dalam produk akhir. Dengan kata lain, ini bertujuan untuk menyampaikan keseluruhan visi desain daripada menentukan segala sesuatu secara tepat sejak awal. CA bukanlah ilustrasi, ini yang perlu digarisbawahi. CA bukanlah semata ilustrasi atau sama dengan ilustrasi, seperti halnya seni ilustrasi dari sebuah buku. CA ini tentang menciptakan satu visi 
artistik yang bisa memberi kekuatan pada keperluan sebuah proyek desain. Dengan demikian dikaitkan dengan animasi, maka CA di sini dipahami sebagai visi artistik yang akan digunakan sebagai pedoman desain untuk keperluan pembuatan film animasi. CA yang dituangkan dalam bentuk ilustrasi ini merupakan implementasi dari sebuah gagasan tentang segala sesuatu yang berkaitan dengan sebuah proyek film animasi. Lalu mengapa harus ada CA dalam film animasi? Kita harus sadar diri, bahwa segala sesuatu yang berkaitan dengan proyek desain, apalagi yang sekelas industri besar, seperti industry animasi, tentu akan mengivestasikan nominal yang tidak sedikit. Kita harus dapat mempertimbangkan berapa jumlah uang yang dihabiskan untuk sebuah film animasi dan bagaimana jika uang itu hilang terbuang percuma jika proyek film animasi gagal. Disinilah dituntut pembuatan konsep art yang visioner dalam arti akan dapat diimplementasikan pada desain animasi yang bisa dijual kepada masyarakat.

CA adalah kunci untuk memfokuskan visi artistik tunggal dan untuk menghilangkan segala keraguan, distorsi, bahkan kesalahan visual yang bisa menjadi masalah. CA dianalogikan sebagai sebuah palet (seni lukis) yang berisi warna-warna pilihan untuk dilukiskan. Konsep seni yang mencakup palet warna dan motif desain yang membantu memusatkan proses produksi dan memastikan penglihatan kita sampai ke produk akhir. Yang harus diingat bahwa CA telah menjadi pedoman visual bagi teamwork yang bekerja dalam suatu proyek, di mana tentu isi kepala mereka berbeda ketika membentuk sebuah ilustrasi atau desain tertentu.

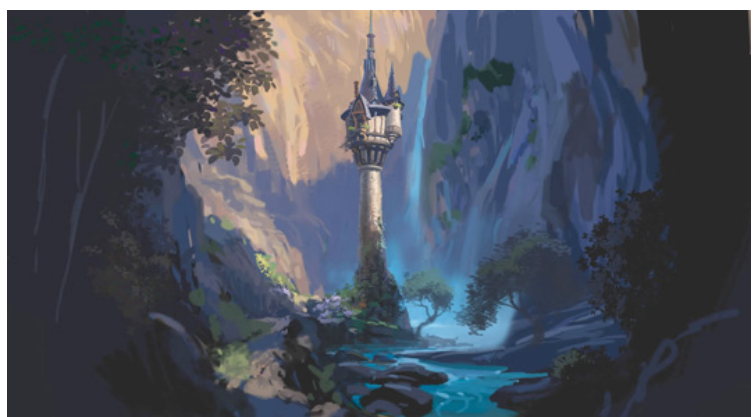

Gambar 1 Konsep art untuk sebuah seting lokasi cerita tempat tinggal di tengah hutan (sumber : creative blog staff, 6 November 2012)

Pada gambar 1 adalah salah satu contoh dari konsep art untuk tempat tinggal yang digambarkan susah untuk akses keluar masuk, karena dibuat meninggi. Hal ini disebabkan lokasinya yang ditengah hutan.Terdapat pertimbangan visi artistik bahwa CA dalam gambar tersebut menyiratkan kepentingan untuk menggambarkan kemungkinan faktor keamanan, sumber penghidupan, yakni air, dan tingkat kesulitan untuk menjangkaunya, tersembunyi dan imajinasi kehidupan budaya masyarakat jaman romantik. 
CA bisa berkisar dari goresan suasana hati hingga skema yang lebih rinci dari properti, atau karakter misalnya. Tujuannya adalah untuk mengurangi margin error, dan karena itu mengurangi waktu dan biaya. Bisa jadi goresan itu membantu menjelaskan ide ke art director atau desain yang benar-benar salah. Intinya adalah, semuanya adalah bagian dari proses, bahkan yang jelek sekalipun. Konsep seni adalah proses yang berulang-ulang. Feng Zhu, salah satu konseptor dalam animasi, menggunakan pendekatan desain industri serupa yang menawarkan banyak pilihan dalam konsep art-nya.Ia memilih untuk mengembangkan gagasannya sendiri untuk sebuah CA tentang bentuk/model pesawat atau kendaraan daripada mendapatkan tim pemodel dan seniman untuk menciptakan hal yang nyata. Feng Zhu membuat banyak pilihan model pesawat, yang menggambarkan kepentingan sebuah industri yang sangat maju dan keluar dari apa yang pernah dibayangkan manusia untuk sebuah struktur pesawat ruang angkasa konvensional (gambar 2).

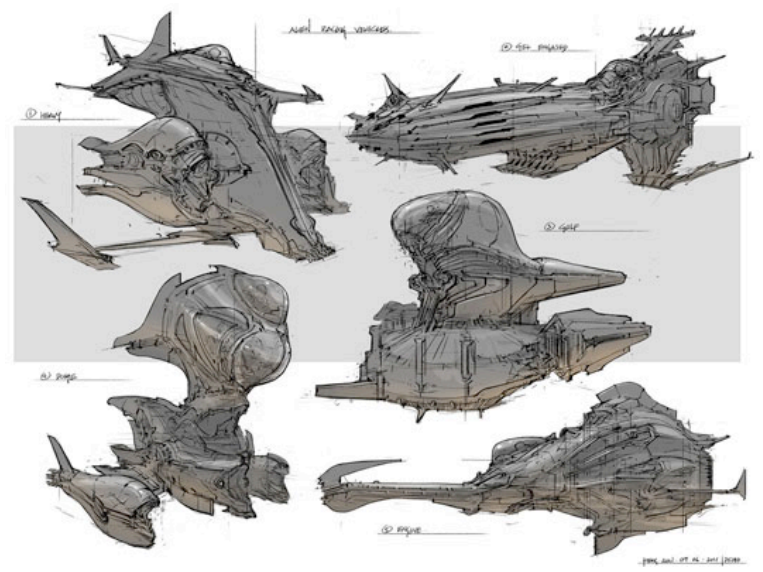

Gambar 2 Konsep art untuk sebuah properti pesawat luar angkasa

(sumber : creative blog staff, 6 November 2012)

Begitu pula dengan penciptaan karakter dalam konteks CA, maka sebenarnya ini adalah sebuah penyempaian bahasa. CA dimengerti sebagai sebuah bahasa visual, di mana ada kata-kata yang dipilih dan digunakan untuk menyampaikan sebuah kalimat. Ketika kita akan membuat sebuah karakter tentang pejuang wanita, maka ada banyak sekali kata-kata atau perbendaharaan kata yang akan dirangkai untuk mengambarkan seperti apakah pejuang wanita tersebut. Dalam gambar 3 dan 4 kita bisa mendesain karakter untuk konteks yang mempunyai banyak pilihan. Banyak sekali faktor eksternal untuk dapat membantu menjelaskan siap karakter tersebut. Dalam gambar 3 dan 4 bisa dibedakan mana karakter wanita yang benar-benar warior atau pejuang, atau karakter wanita yang 
menjadi tentara dalam situasi atau suasana masa depan.

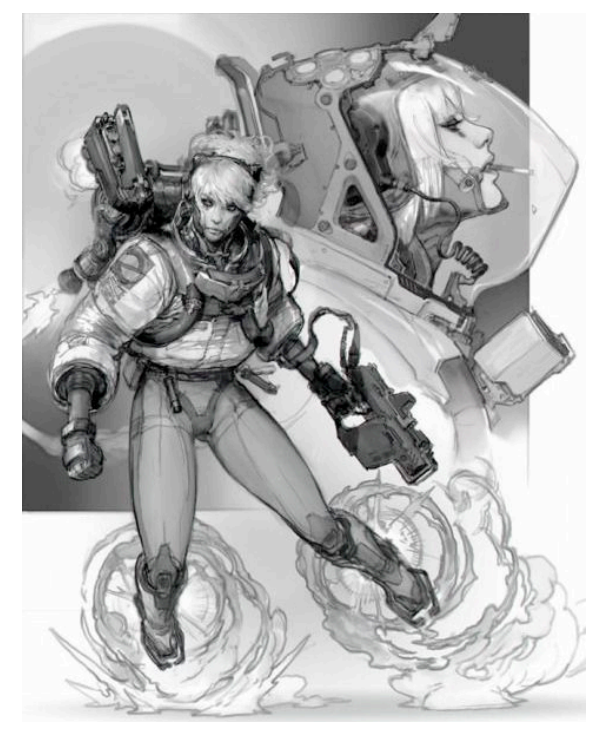

Gambar 3 Wanita dalam atribut tentara masa depan

(sumber: pinterest - rhubarbes.com.)

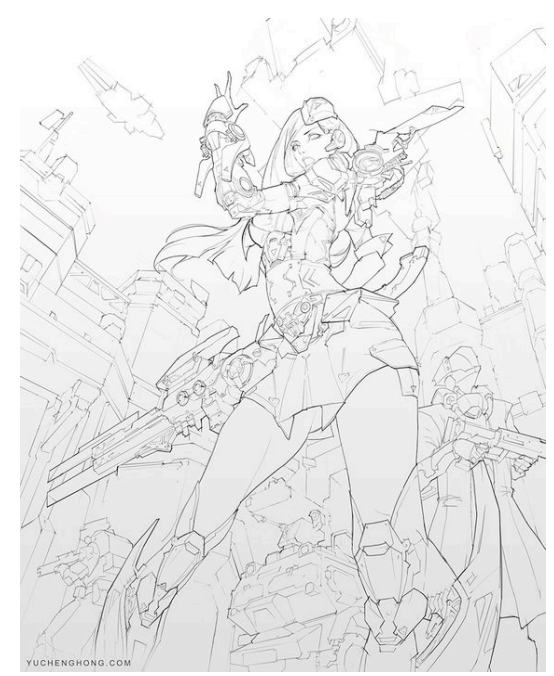

Gambar 4 Pejuang wanita jaman masa depan (sumber: pinterest - artstation.com)

CA dan ilustrasi bukanlah hal yang sama. Kualitas dan teknik keduanya lebih dekat dari sebelumnya dan ada banyak tumpang tindih namun keduanya memiliki satu perbedaan intrinsik. Perbedaan itu adalah kata 'konsep'. Tujuan dari CA disini adalah dengan cepat menggali gagasan dan mengkomunikasikannya seefektif mungkin. Sedangkan peran ilustrasi sendiri adalah sebagai wujud karya dan bentuk kebahasaan secara visual.

\section{Metode Dasar}

CA sebagai sebuah konsep tentu mempunyai prosedur tersendiri untuk dilalui. Seperti halnya brainstrorming yang terus menerus mempertanyakan kemungkinan-kemungkinan untuk goal tertentu, maka CA telah menjadi semacam metode tersendiri ketika ingin merancang sebuah film animasi. Terdapat beberapa pertanyaan yang diakhiri dengan ekseskusi desain dalam tiap aspek CA.

\section{Mengapa perlu karakter}

CA dalam animasi selalu mempertanyakan mengapa perlu karakter, bagaimana bentuk atau wujudnya serta apa saja karakter yang dibutuhkan dalam cerita tersebut. Karakter tentu berkaitan dengan tujuan dari pembuatan karakter, dengan demikian wujud karakter tentu akan merefleksikan hal-hal yang diinginkan oleh animator sebagai label atau identitas yang melingkupinya. Jika karakter tersebut hanya ditujukan untuk beraksi untuk dilontarkan, maka tentu kita tidak perlu 
menggambarkan tangan dan kaki, seperti halnya karakter animasi game angry birds.

Karakter tersebut dibentuk sebagai jawaban untuk tujuan game rules-nya. Sementara dalam film animasi tentu penciptaan karakter tidak dapat dilepaskan dengan ide cerita sebagai sebuah konsep cerita. Banyak aspek yang menjadi konsep background Character ketika diciptakan sebuah karakter atau gagasan tentang karakter. Aspek yang harus diimplementasikan ketika akan menciptakan karakter, haruslah dilihat dari semua sudut pandang untuk memperkuat identitasnya. Metode yang dapat digunakan, adalah menjawab beberapa pertanyaan tentang konsep karakter. Selanjutnya haruslah dianalisis apa yang dapat mencerminkan atau merefleksikan karakter tersebut. Dengan hasil analisis tersebut maka selanjutnya dapat dilakukan studi visual untuk menggambarkan bagaimana rupa atau bentuk karakter tersebut. Dalam Animation Concept Art, ada beberapa pertanyaan yang harus dijawab untuk sebuah studi karakter. Pertama yang harus dijawab - dan tentunya perlu studi tentang orientasi bisnis atau bagaimana nanti terapan animasi ini diterapkan - adalah kita akan merancang animasi apa? Ini sangat berkaitan dengan ide dasar. Konsep dasar tentang kepentingan pembuatan animasi, atau proyek animasi. Apa tujuan karakter dibuat atau untuk apa karakter dibuat (objective definition) haruslah dirumuskan sebagai awal studi. Proses ini tentu bersifat berulangkali sebagai usaha untuk perbaikan dalam rangka memperbarui menuju hasil yang ideal (iteration).

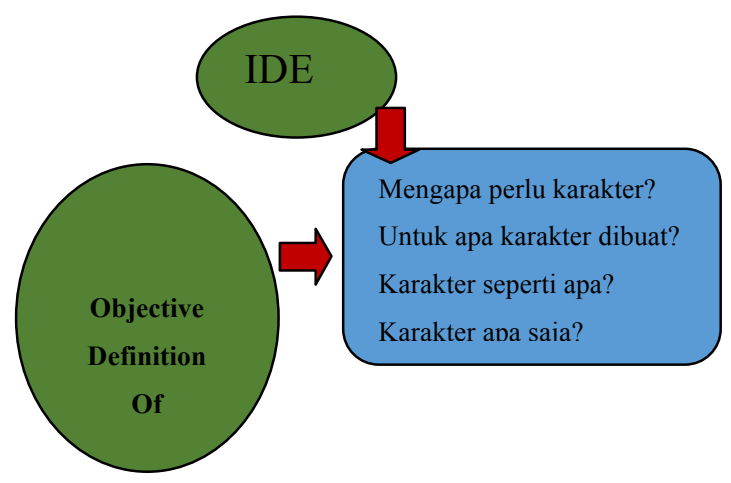

Pertanyaan tentang ide ini, akan menyangkut kepentingan tujuan dari penciptaan karakter, game animation, movie animation, grafik animation atau untuk bagian dari iklan. Dari ide, selanjutnya haruslah dikembangkan melalui pertanyaan umum (objective definition). Hal ini dapat menjadi batasan bentuk dari karakter itu sendiri serta kemampuan anatominya dalam berintraksi. Di sisi lain juga dapat mendifenisikan bagaimana latar belakang karakter, peran dan posisi karakter dalam cerita.

\section{Bentuk Dasar}

Ada kalanya karakter diputuskan untuk mengambil dari bentuk hewan, manusia, 
perabotan, geometris (bentuk dasar), kartun atau sama sekali yang belum pernah dilihat. Mereka kadang dibentuk dengan anatomi yang sederhana atau rumit. Atribut ataupun properti yang dibentuk juga akan menyesuaikan dengan ide penciptaan karakter tersebut. Di sisi lain, kreatifitas perancang ketika mulai membuat karakter harus selalu terbuka dengan semua kemungkinan-kemungkinan. Karakter bisa didekonstruksi dari bentuk apa pun, mulai dari yang sama sekali berbentuk dasar seperti kubus, silinder, bola atau yang meniru dari bentuk-bentuk yang ada disekitar kita, seperti mobil, kap lampu, lilin, pohon dan lain sebagainya. Ini yang menjadi esensi dari perancangan karakter dari animasi, bahwa apa pun obyeknya bisa dianimasikan.

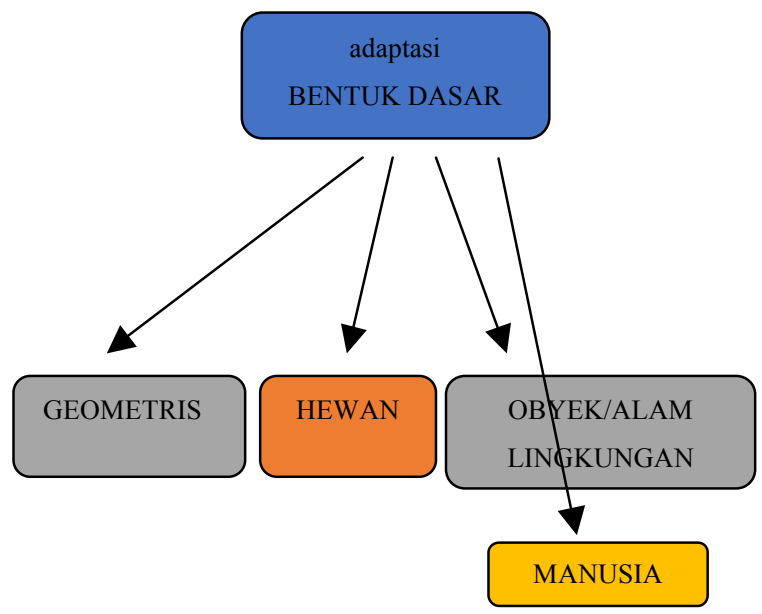

\section{Gender}

Jenis kelamin adalah pembentukan karakter yang mendekatkan kepada sasaran khalayaknya. Audiens akan mudah untuk mengidentifikasi bahwa karakter yang dilihat adalah berjenis kelamin tertentu dengan sifat-sifat yang melekat. Dengan membatasi karakter menurut jenis kelamin, maka karakter yang dibuat tidak menyimpang dari logika berfikir manusia tentang jenis kelamin dan perwatakannya, sebagai sebuah kodrat dan pengalaman manusia (empiric). Dalam hal ini karakter bisa dikelompokkan secara garis besar adalah Laki-laki dan Perempuan.
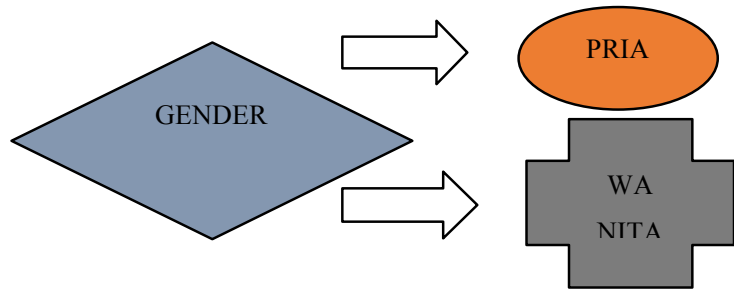

\section{Usia}

Usia akan mencerminkan kemampuan mental dan fisik karakter. Penggambaran usia dalam karakter tidak menunjukkan berapa usianya, akan tetapi cukup dikelompokkan menurut perbedaan siklus usia yang signifikan secara fisik, yakni balita atau bayi, anak-anak, remaja, dewasa, dan tua. Konsep tentang usia untuk berdasar pada kemampuan berinteraksi, tindakan dan adaptasi dengan lingkungan karakter itu sendiri. 


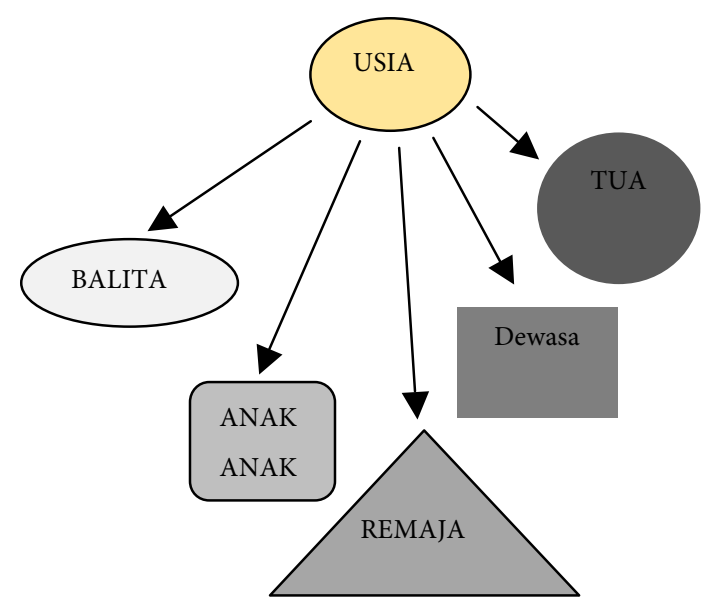

5. Materi

Konsep materi adalah menunjukkan bagaimana kualitas fisik dari karakter, dan ini juga akan berhubungan dengan hukum sebab dan akibat dari suatu tindakan atau pergerakan dari karakter. Jika karakter yang digambarkan mengadopsi materi kaca atau keramik, maka ketika terjatuh akan pecah berantakan. Begitu pula jika digambarkan dengan materi seperti karet, maka akan mempunyai sifat elastis (elongisitas). Materi juga berhubungan dengan hukum nesesitas dari alam seperti adanya gravitasi dan angin. Jika karakter digambarkan seperti manusia, maka segala akibat yang ditimbulkan dari pergerakannya tidak jauh dari hukum sebab dan akibat. Konsep materi berkaitan dengan sifat materi yang digambarkan pada karakter. Meskipun dalam animasi terdapat gaya visual yang artifisial, seperti animasi Walt Disney, akan tetapi konsep materi diwujudkan sebagai pemahaman tentang sifat materi secara fisik.

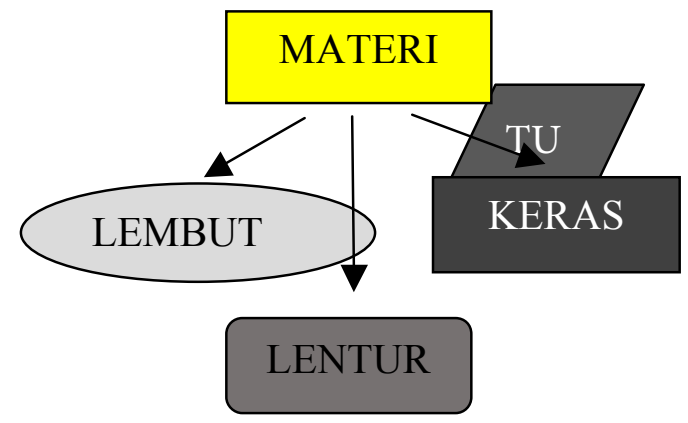

\section{Sasaran Khalayak}

Ketika karakter akan dibuat, tentu sebagai sebuah tontonan, maka animator hendaknya mempertimbangkan siapa nantinya yang akan melihat karya animasi ini. Meskipun animasi sering diidentikkan dengan tontonan anak-anak, namun saat ini animasi sudah popular di kalangan orang dewasa. Banyak animasi yang dibuat oleh perusahaan animasi yang dibuat untuk layar lebar (cinema) yang dilihat oleh banyak orang dewasa. Yang membedakan tentu pendekatan storytelling-nya. Dengan membatasi siapa sasaran khalayaknya, maka ide penceritaan dan karakter yang dibuat akan lebih mudah untuk dibentuk, menyesuaikan dengan daya pikir atau nalar audiens. Karakter yang begitu rumit mungkin tidak mudah untuk anak-anak memahami bagaimana perbedaan tiap karakter dan personality-nya. 


\section{Penjaringan Ide dan Drawing Karakter}

\section{Kepribadian}

Pemahaman tentang karakter yang mempunyai daya tarik (appeal) terletak pada kepribadian atau personality dari karakter. Dia disebut sebagai kata karakter, karena terdapat watak dan sifat yang bisa ditunjukkan, sehingga penonton bisa melihat bagaimana karakter menggambarkan adegan-adegan yang seakan akan muncul dari suasana hatinya. Apalagi jika karakter ini berperan dalam sebuah cerita yang terdapat peran antagonis maupun protagonisnya. Karakter dengan kepribadian juga dapat menunjukkan latar belakang dari karakter itu sendiri, seperti apakah berlatar belakang militer atau agama. Kepribadian dari karakter perlu dimunculkan untuk mempermudah penonton mengidentifikasi atau mengenal siapa itu dia. Bahkan sifat atau temperamen bisa dilekatkan kepada karakter lewat bentuk anatomi itu sendiri, seperti superhero, pemalas, pembuat onar dan lain sebagainya.

\section{Latar Belakang Karakter}

Untuk sebuah perancangan film animasi, latar belakang karakter perlu dideskripsikan agar wujud karakter dapat dengan mudah dibentuk. Untuk karakter yang identik dengan montir atau bankir, tentu mempunyai wujud karakter yang berbeda. Konsep latar belakang karakter ini sebagai material yang berguna mewujudkan bagaimana membentuk postur dan mengenali karakter itu sendiri. Latar belakang karakter menjadi penting ketika karakter telah menjadi bagian dari setting cerita. Ketika animator merancang karakter dengan ide cerita peperangan, maka dia harus memikirkan bagaimana seharusnya karakter-karakter ini digambarkan. Begitu pula jika ide ceritanya menunjukkan sebuah peradaban, seperti futuristic style, old civilization, budaya saat ini, atau mungkin 20 tahun yang lalu dan sebaliknya. Bisa juga animator berimajinasi tentang kehidupan alam lain. Peradaban dan Budaya menjadi penting sebagai aspek latar belakang karakter. Ada baiknya sebelum menggambarkan karakter, animator harus dapat menceritakan siapa sebenarnya karakter tersebut, mengapa dia digambarkan seperti itu.

LATAR BELAKANG KARAKTER

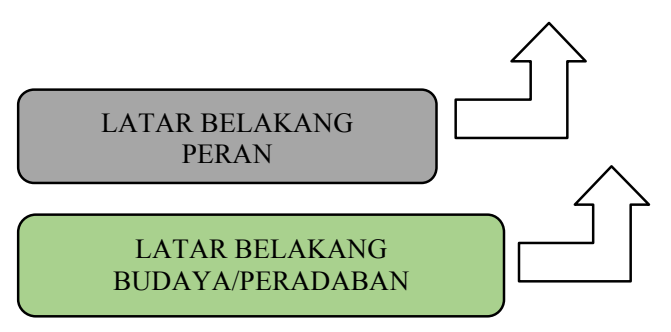




\section{Peran}

Karakter dibentuk atau digambarkan sebaiknya tidak melupakan peran yang diadegankan. Untuk sebuah cerita superhero, tentu peran yang digambarkan adalah mendekatkan pada kebaikan, begitu pula sebaliknya untuk peran jahat, maka karakter yang dibentuk akan mengindikasikan unsur kajahatan. Inilah mengapa karakter licik dan jahat selalu mengadobsi hewan-hewan karnivora, ular misalnya. Ini tidak lepas dari stereotype atau anggapan umum di masyarakat. Meskipun demikian peran ini tidak selalu harus pada area yang jelas. Adakalanya karakter dibuat untuk menggambarkan bahwa karakter dengan bentuk liar atau monster pada akhirnya pada posisi protagonist. Jenis karakter yang dibuat tetap mengacu pada peran dalam ide cerita. Jika ada dua karakter yang berbeda sama sekali seperti karakter dan monster, akan tetapi tidak selalu karakter monster berada di posisi peran jahat. Sekali lagi penggambaran karakter ini sebaiknya dirumuskan berdasarkan konteks ceritanya. Sebab ketika kita menggambarkan karakter dengan muka rusak, misalnya, tentu ada penjelasan logis di dalamnya...entah akibat dari peperangan atau kecelakaan. Seperti halnya karakter bajak laut bertangan pengait, tentu itu tidak dibuat asal-asalan. Jadi sebelum membuat karakter sebaiknya ada behind story of character untuk menjelaskan siapa sebenarnya karakter tersebut.

\section{Anatomi}

Ilustrator atau animator pada dasarnya harus memahami tentang anatomi ketika menggambarkan sebuah karakter. Dikaitkan dengan bentuk dasar yang akan diimprovisasikan, tentu karakter pada dasarnya mempunyai anatomi. Ini untuk mempermudah animator membuat adegan adegan karakter. Jika memang harus bisa 'berlari' tentu ada kaki, dan jika bisa 'melihat' tentu ada mata dan seterusnya. Anatomi terkait dengan kepentingan bentuk karakter dalam rules of the act. Panjang pendek, besar kecil, lonjong, bulat, dan seterusnya adalah konsep tentang anatomi. Jika animator ingin menggambarkan karakter yang kuat, tentu hubungan perbandingan anatomi terhadap ukuran menjadi penting. Begitu pula jika animator ingin menggambarkan karakter yang imajinatif tentu perbandingan anatomi dengan bentuk dan jumlah anggota tubuh menjadi penting. Sekali lagi anatomi dapat menggambarkan secara fisik identitas dari karakter. 


\section{Proporsi}

Dengan berdasar pada anatomi, maka illustrator atau animator bisa mempertimbangkan hubungan antara latar belakang, peran dan anatomi, ke dalam penggambaran karakter terkait bagaimana proporsinya. Tak jarang animator ketika membuat karakter orang kaya, selalu dibuat dengan perut bumcit. Proporsi perut, lengan, kepala, kaki, tangan, ataupun struktur tubuh yang lain perlu dipertimbangkan untuk menggambarkan bagaimana personalitinya. Dalam hal ini terdapat 4 pertimbangan terkait proporsi, yakni perwatakan, ukuran, bentuk dasar dan style.

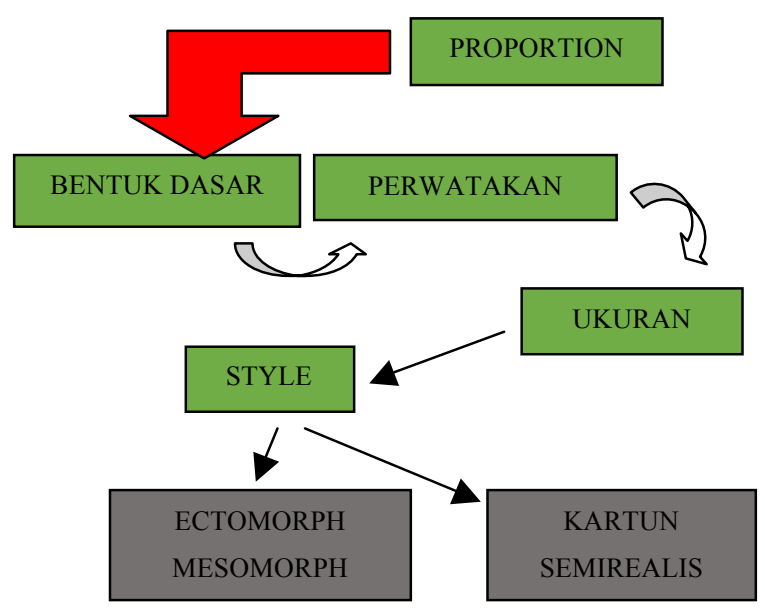

\section{Fleksibilitas dan Nesesitas}

Karakter tentu tidak hanya diam, dia akan bergerak untuk mengesankan 'hidup'. Pengertian hidup ini adalah bergerak sesuai keinginan dari karakter (Roger Manwell; 1971; 23). Ini tentu berbeda dengan digerakkan. Konsep bergerak dan digerakkan adalah konsep yang bertolak belakang. Dengan makna yang bersifat aktif, maka karakter ketika bergerak akan sangat tergantung dengan anatomi dan proporsinya. Dengan demikian animator atau desainer harus mengerti benar bagaimana struktur anatomi dari karakter memberikan fleksibilitas untuk bergerak. Jika karakter perlu melompat, maka tentu ada kaki yang ditekuk untuk mengesankan kemampuan melenting, dengan demikian kaki yang sangat pendek sekali tidak memberikan ruang untuk sendi yang ditekuk, dan ukuran menjadi penting dalam kasus ini. Di sisi lain ada faktor yang mempengaruhi fleksibilitas karkater yakni hukum alam atau nesesitas. Ketika animator memutuskan untuk memberikan sayap kepada karakter, maka harus dipertimbangkan apakah sayap seperti burung untuk memberikan kesan kemampuan menekan dan mendorong udara, ataukah sayap untuk pesawat yang tidak mempunyai daya dorong. Fleksibilitas dan nesesitas berjalan seiring dalam anatomi dan struktur karakter.

\section{Pembedaan}

Karakter yang tidak begitu dapat dibedakan akan sulit untuk diidentifikasikan sebagai karakter yang mempunyai peran dalam 
penceritannya. Pembedaan karakter harus kuat dan sesuai dengan maksud dan tujuan pembuatan karakter dalam konteks cerita. Pembedaan ini tidak serta merta berbeda akan tetapi juga harus sesuai dengan peran dan latar belakang karakter. Pembedaan tidak hanya merubah atau mendistorsi ukuran serta anatomi karakter, melainkan harus mencerminkan bahwa karakter tersebut berbeda karena mempunyai watak atau kepribadian yang tidak sama.

\section{Melebih Lebihkan}

Ada kalanya animator memberikan ruang untuk melebih-lebihkan bentuk karakter, semata untuk memperkuat imajinasi terhadap karakter atau memberikan nuansa-nuansa lain seperti kelucuan, kekonyolan, ketololan atau kengerian sekalipun, yang tidak masuk akal logika manusia.

\section{Aksesoris / Atribut}

Konsep terhadap karakter tidak dilepaskan dari aksesoris atau atribut. Ini untuk menjelaskan bahwa karakter akan membawakan peran dan ceritanya sendiri. Jika karakter yang dibuat adalah tentara masa depan, maka dia akan selalu menenteng atribut ketentaraannya tersebut, atau jika dia seorang bajak laut abad 1500, maka pedang tidak lepas dari pinggangnya.
Koboi tidak lepas dari topi khas koboi, pistol dan sepatu lars. Aksesoris atau atribut tidak dapat dilepaskan dari latar belakang karakter, peran dan peradaban yang melingkupinya.

\section{Penjaringan Ide Karakter}

\section{Pertulangan}

Tidak semua animator memahami benar bagaimana sebenarnya pertulangan dari organisme. Penjaringan ide karakter yang diawali dari pertulangan adalah sebagai kontrol terhadap postur, ukuran dan posisi anatomi dari karakter. Animator tentu tidak akan membuat struktur tulang tegak lurus untuk karakter 'pemalas' atau 'letih'. Bentuk pertulangan badan akan dibuat melengkung ke depan untuk memberikan kesan acuh dan malas terhadap situasi sekitarnya atau pun kondisi letih. Pertulangan akan sangat membantu membentuk anatomi dan fleksibilitas pergerakan. Pertulangan juga akan sangat membantu bagaimana menggambarkan karakter beradegan tertentu, seperti melompat, terjatuh, berkelahi dan sebagainya. Pertulangan adalah sebagai guideline untuk menunjukkan aksi dari karakter.

\section{Kepala}

Mengapa kepala perlu mendapat perhatian dalam konsep art tentang karakter? Kepala 
adalah pusat kontrol dari anatomi. Kepala menjadi tumpuan untuk memahami karakter ketika berinteraksi. Kepala adalah pusat dari gambaran tentang ekspresi dan komunikasi dengan penonton. Kepala adalah anatomi yang dapat menggambarkan identitas serta perbedaan dengan karakter lain, karena menjadi titik perhatian terhadap karakter. Kepala adalah anatomi yang memberikan perwajahan kepada karakter.

\section{Sketsa Karakter}

Pada tahapan ini konsep tentang karakter sudah siap untuk divisualisasikan. Namun ada kalanya animator kurang yakin dengan hasil gambar tentang karakter, dengan demikian perlu dikembangkan alternatif gambar dalam bentuk sketsa. Sketsa merupakan gambar awal yang secara visual adalah proses menuju gambar final. Dalam tahapan sketsa dapat dikembangkan alternatif-alternatif bentuk yang sesuai dengan konsep karakter. Dalam tahapan sketsa pula dapat dikembangkan secara artistik tentang anatomi ataupun atribut yang melekat pada karakter. Meskipun sketsa karakter hanya bersifat coretan gambar yang saling tumpang tindih, dan menggambarkan bentuk karakter secara kasar, akan tetapi tahapan ini adalah sebuah proses yang harus dilalui, sebagai upaya untuk mencari bentuk karakter yang ideal. Ukuran perut yang buncit akan dapat digambarkan dengan berbagai pilihan melalui sketsa. Seberapa besar proporsi kepala dapat digambarkan dengan beberapa pilihan melalui sketsa. Sketsa adalah sebuah gambar awal yang menyodorkan alternatif pilihan secara artistik dan dapat dikembangkan menjadi gambar karakter yang diinginkan.

\section{Final Karakter}

Dari alternatif sketsa karakter yang sudah dibuat, dipilih satu karakter yang sudah dapat mengakomodir pertimbanganpertimbangan tentang karakter sebagai karakter jadi atau final karakter. Dalam final karakter ini, figur sudah digambarkan dengan jelas, baik garis, warna dan atributatribut yang disandangnya. Final karakter adalah gambaran utuh tentang desain karakter yang akan menjadi tokoh dalam animasi. Proses membentuk final karakter ini sering diistilahkan dengan modeling.

\section{T-Pose/Turn Arround}

Untuk mempermudah animator dalam mengimplementasikan karakter ke dalam berbagai posisi adegan, maka final karakter harus ditampakkan dari beberapa sudut pandang, mulai dari tampak depan, samping dan belakang. Penggambaran 
karakter dengan sudut pandang yang berbeda ini, adalah untuk mempermudah animator melihat bentuk karakter secara menyeluruh, sehingga apa yang tampak dari belakang atau samping dari karakter dapat dipahami ketimbang hanya melihat dari depan. Penggambaran dari beberapa sudut pandang ini dinamakan dengan T-pose, untuk memperlihatkan bagaimana anatomi, proporsi serta postur karakter dilihat dari beberapa sudut pandang. Akan halnya diistilahkan dengan T-pose, karena jika karakter mempunyai tangan, maka anatomi tangan digambarkan terangkat menyamping, menyerupai huruf $\mathrm{T}$.

Memperlihatkan desain karakter dari beberapa sudut pandang ini, akan lebih sempurna jika digambarkan tidak hanya dari depan, samping dan belakang, akan tetapi dari sudut pandang yang lebih banyak, seperti kalau kita memutar pelanpelan suatu obyek dari depan sampai ke posisi semula. Dengan Turn-arround, kita dapat melihat detail dari karakter secara jelas, karena telah digambarkan dari banyak sudut pandang putaran (0 derajat, 45 derajat, 90 derajat, 135 derajat, 180 derajat, 225 derajat, 270 derajat, 315 derajat dan kembali ke posisi semula 360 derajat atau 0 derajat)

\section{Acting}

Karakter adalah tokoh atau subyek yang berperan dalam cerita animasi. Karakter adalah figur yang nampak hidup dan bergerak. Karakter adalah adalah figur yang akan beradegan dalam film animasi. Karakter akan bergerak, beraksi dan melakukan adegan-adegan sesuai dengan cerita yang dikehendaki. Dengan demikian ketepatan dalam menggambarkan adeganadegan dari karakter sebagai sebuah aksi atau acting akan menjadi sangat dibutuhkan. Jika karakter dalam cerita tersebut akan beradegan atau berakting banyak hal, maka animator harus dapan menggambarkan model aksi-aksi dari karakter sebagai panduan pose adegan dari karakter. Hal ini mengingat bahwa sebuah film animasi, terkadang dikerjakan oleh beberapa animator untuk mengerjakan aksiaksi karakter yang sama. Kesamaan pemahaman tentang aksi-aksi karakter akan dipermudah dengan membuat banyak aksiaksi dari karakter yang akan menjadi 'acting' dari karakter. Pedoman aksi selain menunjukkan beberapa pose aksi, juga akan menjadi panduan dalam menggambarkan sudut pandang anatomi, proporsi, serta atribut yang dikenakannya. Pedoman aksi ini akan menyesuaikan seberapa jauh karakter akan beraksi atau beradegan dalam keseluruhan cerita. Jika memang film cerita 
ini hanya tentang roman dan berisi dialog antar karakter, maka tidak perlu digambarkan adegan perkelahian dari karakter dan seterusnya.

\section{Facial Cues}

Wajah adalah petunjuk dari suasana hati. Begitulah yang sering dipahami oleh banyak orang. Wajah yang meliputi mata, hidung, dahi dan mulut akan bereaksi untuk mengekspresikan sebuah rasa atau mood. Untuk menjadikan pedoman karakter ketika menggambarkan ekspresi ataupun suatu mood, maka haruslah dibuat beberapa ekspresi wajah (facial cues) yang menggambarkan identifikasi dari ekspresi atau mood tertentu, mulai dari ekspresi ketika berbicara, mendengarkan, sedih, marah, terkejut, takjub, ketakutan, tertawa, gembira dan lain sebagainya. Dalam animasi ekspresi wajah perlu diperlihatkan sebagai dramatisasi mood sehingga akan lebih mudah ditangkap oleh penonton. Selanjutnya akan lebih optimal jika ekspresi wajah ini dikombinasikan dengan penggambaran sebagian anatomi karakter, untuk memperlihaatkan bagaimana anggota tubuh yang lain dari karakter bereaksi ketika menggambarkan perasaan mood tertentu tersebut.
Penjaringan Ide dan Drawing Desain Lingkungan

\section{Lingkungan Karakter}

Merancang atau mendisain karakter tidak harus dimulai dari sketsa karakter itu sendiri, akan tetapi akan lebih optimal atau menjiwai jika animator ataupun illustrator dapat berimajinasi atau membayangkan bagaimana lingkungan dari karakter tersebut. Jika illustrator membayangkan ide ceritanya akan bernuansa kerajaan di jawa, maka desain karakter akan lebih mudah untuk digambarkan, karena kode-kode budaya sudah bisa diimajinasikan, seperti bagaimana bentuk rumah, halaman, pohon, kendaraan dan lain sebagainya sebagai pedoman awal dari lingkungan penceritaan. Desain lingkungan pada dasarnya akan membentuk persepsi dari setting cerita yang akan dibawakan dalam film animasi.

\section{Setting Adegan}

Selain desain lingkungan, kebanyakan karakter akan beradegan tidak hanya di satu tempat, sehingga perlu dibuat pedoman desain setting adegan. Desain setting adegan hendaknya menyesuaikan seberapa banyak lokasi dan situasi tempat yang akan digunakan untuk menggambarkan lingkungan adegan dari karakter. Sebagai contoh illustrator dapat menggambarkan 
bagaimana ruangan untuk adegan menggambarkan kumuh-bersih, privatpublik, rumah-kantor, restricted area seperti kamp militer-area pengungsian dan lain sebagainya. Sekali lagi, untuk mengidentifikasi setting adegan maka, harus dipahami terlebih dahulu bagaimana ide dasar dari jalan cerita film animasi ini akan dibuat.

\section{Penjaringan Ide dan Drawing Property}

Properti adalah desain dari obyek-obyek yang digambarkan dalam desain lingkungan maupun obyek yang terkait dengan karakter. Sebagai contoh misalnya film animasi menggambarkan tokoh ben-hur yang hidup di masa romawi kuno, maka properti yang melingkupi kereta kuda untuk raja dan bangsawan tentu berbeda dengan kereta kuda untuk rakyat jelata. Sebagai sebuah CA, animator dan illustrator harus jeli dalam memperlihatkan properti yang ada dalam setting adegan. Ini adalah untuk menunjukkan bahwa ide tentang latar belakang karakter dapat diintegrasikan dengan baik melalui properti yang ada.

\section{Storytelling}

Konsep tentang storytelling adalah konsep yang sangat mendasar dalam cerita film. Daya tarik dalam film terletak pada bagaimana alur cerita (plot) yang disampaikan kepada penonton. Terdapat 3 aspek yang perlu dipahami oleh pembuat cerita, yakni tema dan premis, karakterisasi, dan alur cerita atau plot.

\section{Tema dan Premis}

Tema adalah pokok pikiran dari cerita atau garis besar dari cerita yang akan disampaikan kepada penonton. Tema bisa berupa petualangan, cinta, persahabatan, balas dendam, dan sebagainya. Tema dapat disetingkan dengan latar belakang apapun juga. Kisah persahabatan dapat disuasanakan dalam situasi peperangan atau petualangan. Begitu juga balas dendam, dapat disetingkan dengan suasana horror atau petualangan bahkan ekspedisi. Tema di sini adalah inti cerita dari keseluruhan cerita. Sedangkan Premis adalah makna yang ingin disampaikan kepada penonton, bahwa perselingkuhan membawa bencana keluarga. Cinta mengalahkan materi dan keduniawian. Persahabatan mengalahkan dendam, dan sebagainya.

\section{Karakterisasi}

Dalam karakterisasi ini, cerita yang disampaikan hendaknya dapat menceritakan $2 \mathrm{~W}$, yakni Who dan Why. Cerita hendaknya dapat menggambarkan siapa sebenarnya karakter tersebut dan mengapa karakter tersebut bertindak atau 
berbuat seperti itu. Jika karakter tersebut adalah monster, maka setidaknya ada porsi khusus yang tidak banyak untuk menjelaskan latar belakang kehidupan monster tersebut sehingga peran dan perwatakannya dapat diinterprestasikan. Demikian pula jika monster tersebut berperilaku kasar atau jahat tentu ada latar belakang mental atau psikologis sehingga ada korelasi antara perilaku dan beban mentalnya. Ini semua juga berkaitan dengan aspek peran dalam karakterisasi.

\section{Plot}

Plot atau alur cerita adalah bagian dari storytelling yang dapat menumbuhkan daya tarik film. Secara sederhana plot untuk storytelling ini dibagi menjadi 3 babak (sequence), yakni tahap awal yang berisi tentang pengenalan karakter dan situasi yang melingkupinya, kemudian babak tengah, yang berisi tentang konflik dan inti dari permasalahan. Kemudian babak akhir yang biasanya menggambarkan premis dari cerita, bisa tragedy atau biasanya happy ending. Plot dirangkai harus berdasarkan sasaran khalayak, tidak semua konflik atau puncak masalah harus selalu bersifat fisik, akan tetapi berselisih pandangan atau pendapat juga bisa menjadi konflik, dan ini disesuaikan dengan cara berfikir atau kemampuan penonton dalam mempersepsi cerita. Meskipun plot bukanlah gambar, akan tetapi dengan menentukan garis penceritaan, akan sangat berguna dalam proses visualisasinya yakni dalam bentuk storyboard.

\section{Storyboard}

Di dalam film animasi, storyboard dapat menggantikan naskah cerita atau script, hal ini disebabkan bahwa animasi terbentuk berdasarkan gambar (visual) dan bukan perekaman dari alam (live). Dengan demikian storyboard akan menjadi penting, untuk menunjukkan dua hal sekaligus, yakni jalan cerita serta pedoman gambar adegan-adegan visual dan materi-materi visual yang lain dari awal sampai akhir cerita. Melihat betapa pentingnya storyboard dalam perancangan animasi, maka pembuatan storyboard untuk animasi ini dibuat cukup detail, yakni bagaimana posisi awal adegan pertengahan adegan sampai posisi akhir adegan. Dengan pembuatan storyboard yang detail ini, maka akan mempermudah para animator yang akan membuat gambar-gambar kunci dan inbetweener melakukan penggambaran reka adegan (2D). Dalam animasi 3D, penggambaran storyboard yang digambarkan bagaimana kejadian sebuah adegan, maka akan sangat berguna bagi animator untuk menganimasikan gerakan 
adegan dari model karakter yang sudah ada (animating). Melihat storyboard dalam animasi, seakan-akan melihat gambaran utuh dari film.

Pedoman gambar dalam storyboard selain menggambarkan rangkaian adegan dari awal sampai akhir (1 scene), juga menggambarkan bagaimana sudut pandang dan keluasan areanya. Di dalam film dikenal dengan istilah 'angle', yakni cara penggambaran yang disesuaikan dengan teknik pengambilan kamera, seperti closeup, medium shot, high angle shot, long shot, tracking shot, zoom in/out dan sebagainya. Perbedaan angle yang digambarkan pada storyboard menggambarkan adanya perbedaan titik perhatian dalam sebuah adegan. Untuk adegan dialog dengan frame close-up, maka animator tidak perlu memvisualisasikan seluruh postur karakter, dan cukup hanya kepala dan wajah. Perbedaan angle pada frame storyboard, adalah sebagai bentuk tata bahasa dalam bahasa film yang merujuk pada pengetahuan tentang cinematography. Roger Noake mengatakan bahwa "storyboard is a series of small consecutive drawings ploting key movements in a film narrative, accompanied by caption like descriptions of the action and sound, which are arranged comic-strip fashion and used to plan a film"

\section{KESIMPULAN}

CA adalah representasi atau sekumpulan gambar-gambar yang menjadi konsep dalam perancangan animasi ataupun film animasi yang berbasis industri. CA menjadi metode dasar yang akan mempermudah proses produksi animasi, karena telah menjadi pedoman visual dari materi-materi visual yang akan dilihat oleh penonton. CA merupakan model berfikir kreatif yang terbentuk dari sentuhan-sentuhan artistik dari seniman atau desainer ketika menuangkan gagasan dan pengalaman estetiknya untuk membahasakan secara konstruktif dari apa yang menjadi ide, rasa, dan imajinasinya ketika menangkap sebuah gagasan yang tentang materi visual.

\section{REFERENSI}

[1] John Halas and Roger Manvell, The Technique of Film Animation, Focal Press, London and New York

[2] Kit Laybourne, The Animation Book, a complete guide to animated filmmaking from flip books to sound cartoons, Crown Publisher, Inc, New York. 1981.

[3] Nick Zangwil, Aesthetic Creation, Oxford University Press, New York, 2007

[4] Roger Noake, Animation Techniques, Planning and Production Animation With Today's Technologies, Chartwell Books, Inc., 1990

[5] Shamsuddin, Animation, Concept Art, Dynamic Drawing, Perspective, Journal of Modern Science and Technology, Vol. 2. 2014 